\title{
Hormesis effect of 2,4-D choline salt on soybean biometric variables
}

\author{
Guilherme H.R. Pinheiro ${ }^{1}$, Ricardo F. Marques ${ }^{2 *}$, Prissila P.S. Araújo ${ }^{1}$, Dagoberto Martins ${ }^{2}$, \\ and Sidnei R. Marchi ${ }^{3}$
}

\begin{abstract}
${ }^{1}$ Universidade Federal de Goiás, Regional Jataí, Rodovia 364, km 192, CEP 75804-020, Jataí, Goiás, Brasil. ${ }^{2}$ Universidade Estadual Paulista, Faculdade de Ciências Agrárias e Veterinárias (FCAV), Via de Acesso Professor Paulo Donato Castellane, s/n, CEP 14884-900 Jaboticabal, São Paulo, Brasil. *Corresponding author (rfmarques94@ gmail.com).

${ }^{3}$ Universidade Federal de Mato Grosso, Campus do Araguaia, Avenida Valdon Varjão, CEP 78.605-091, Barra do Garças, Mato Grosso, Brasil.
\end{abstract}

Received: 3 March 2021; Accepted: 3 August 2021; doi:10.4067/S0718-58392021000400536

\begin{abstract}
Auxin-based herbicides, such as 2,4-dichlorophenoxyacetic acid (2,4-D), are lethal to plants at higher doses, but can enhance plant growth at nontoxic concentrations. The stimulating effect of low doses of a substance considered toxic is known as hormesis. This study used dose-response curves to assess the hormesis effect of low doses of 2,4-D choline salt herbicide on soybean (Glycine max (L.) Merr.) biometric variables with distinct growth habits at different phenological stages. A completely randomized experimental design with seven replicates was used, and the treatments consisted of six fractions of the average dose indicated on the label of 2,4-D choline salt formulation: 0 (control), 0.068, 0.684, 6.84, 68.4 and $684 \mathrm{~g}$ ae ha-1 $^{-1}$ applied at the plant's phenological stages second node with fully developed leaves (V2) or fifth node with fully developed leaves (V5). The plants were assessed for their main biometric parameters. The results were analyzed by ANOVA and, when significant, the hormesis model was tested. The maximum effect of hormesis on the main biometric parameters of soybean plants was estimated for doses between 0.20 and $36.01 \mathrm{~g} \mathrm{ae} \mathrm{ha}^{-1}$ of the herbicide and varies depending on the evaluated phenological stage of the plants. Low doses of 2,4-D choline salt herbicide may increase shoots, roots and total DM when applied at stages V2 and V5 of soybean with determinate growth habit and V2 of indeterminate growth habit. There was no adjustment of the hormesis model for the soybean plant with indeterminate growth habit at stage V5.
\end{abstract}

Key words: 2,4-Dichlorophenoxyacetic acid, Glycine max, low doses, morphology, synthetic auxin.

\section{INTRODUCTION}

The herbicide 2,4-dichlorophenoxyacetic acid, commonly known as 2,4-D, is considered as one of the herbicides most largely used worldwide in the last $70 \mathrm{yr}$. This success is mainly due to its high efficacy, low cost, selectivity for grasses, and for being an alternative for the control of weeds that are resistant to other herbicides like glyphosate. It is also considered as a key tool for desiccation applications in crop lands where no-tillage system is adopted (Foloni, 2016). Commercial formulations of this herbicide are also easily soluble in water, oil and other solvents, allowing its rapid penetration into roots and leaves, making it a more effective herbicide (Islam et al., 2017).

The development of cotton and soybean cultivars resistant to 2,4-D has caused a great concern due to the potential risk of accidental use of this herbicide in sensitive crops (Blanchett et al., 2017). 2,4-Dichlorophenoxyacetic acid can easily enter the atmosphere by volatilization, drift, and leaching or run-off due to its high volatility and solubility in water, resulting in potential damages to sensitive crops such as soybean (Niu et al., 2018). According to Silva et al. (2018) 
contamination by 2,4-D herbicide may pose adverse effects on the morphological and physiological variables of soybean crops, and directly affect grain yields.

However, some toxic substances may be stimulating or even beneficial at low doses. This is the case of drugs that are used for their beneficial effects in humans, as well as chemicals products that are usually used as toxic substances to weeds, insects and diseases but can enhance plant growth at nontoxic concentrations. Such stimulating effect of a low toxin dose is known as hormesis (Egan et al., 2014) and is related to adaptive responses of biological systems to moderate challenges through which the system improves its functionality and/or tolerance to more severe future challenges (Calabrese and Mattson, 2017).

Even a regular herbicide application may induce hormesis, i.e., when low doses are nonintentional, as by drift deposition, small-scale dosages heterogeneity, contact with leaves of treated and nontreated plants, umbrella effect, resistance to herbicides and tank contaminations (Velini et al., 2010; 2017). As all herbicides act in plant-critical pathways or processes, low doses of any herbicide can be used to modulate plant growth, development, productivity or composition (Brito et al., 2018).

Auxin-based herbicides, such as 2,4-D, are examples of chemical products that enhance plant growth at nontoxic concentrations, but are lethal at higher doses (Americo et al., 2017). Known as a growth regulator, synthetic auxin or hormonal herbicide, 2,4-D belongs to the class of auxin-mimicking herbicides, because at low concentrations it has physiological and biochemical effects similar to those of the indole-3-acetic acid (IAA), the main natural auxin present in plants (Vanneste and Friml, 2009). Thus, it is expected that the hormesis effect of the 2,4-D herbicide may cause an increase of auxins production and activity, with adverse impacts on the plant's growth and development (Tavares et al., 2017).

However, most studies found in literature investigated the herbicide effect of high doses of 2,4-D on soybean crops. Some few works that examined the effect of low doses of this herbicide did not use dose-response curves to explain the observed events, which may jeopardize proper identification of the hormesis effect (Cedergreen et al., 2005). In addition, they used the amine formulation, and for this reason they cannot represent the future soybean production conditions in the world, where a formulation containing choline salt will be used (Marques et al., 2019; 2021).

Given the above, the aim of this study was to use dose-response curves to assess the hormesis effect caused by low doses of 2,4-D choline salt formulation on biometric variables of two soybean (Glycine max (L.) Merr.) cultivars with distinct growth habits at different phenological stages.

\section{MATERIAL AND METHODS}

The experimental phase of this research was represented by two studies carried out in 2019 under greenhouse conditions, located at Barra do Garças (1552’29,4” S, 52¹8’35,1” W), Mato Grosso, Brazil.

The plots consisted of plastic pots with a capacity of $20 \mathrm{~L}$ filled with soil samples collected from the plowable layer of a humic dystrophic red-yellow Latosol. The chemical and physical characteristics of this soil were: $\mathrm{pH}$ in $\mathrm{CaCl}_{2} 4.4 ; 70.0 \mathrm{~g} \mathrm{dm}^{-3}$ organic matter; nonsignificant P-resin values; $9.5 \% \mathrm{~V}$, and $\mathrm{K}, \mathrm{Ca}, \mathrm{Mg}$ and $\mathrm{H}+\mathrm{Al}$ of $0.21,0.63,0.22$ and $10.0 \mathrm{cmol}_{\mathrm{c} \mathrm{dm}}{ }^{-3}$, respectively; $695 \mathrm{~g} \mathrm{dm}^{-3}$ sand, $125 \mathrm{~g} \mathrm{dm}^{-3}$ silt and $180 \mathrm{~g} \mathrm{dm}^{-3}$ clay. Based on the soil analysis, fertility and acidity corrections comprised $30 \mathrm{~g} \mathrm{dm}^{-3}$ dolomitic lime and $0.35 \mathrm{~g} \mathrm{dm}^{-3}$ simple superphosphate.

The substrate in the pots was kept moist during the experimental period using automatic irrigation set to dispense a volume of water close to the soil field capacity. Maximum, minimum and average daily temperatures in the interior of the greenhouse during the experiment were obtained through a humidity and temperature datalogger (ezTemp-10, Minipa, São Paulo, Brazil) with calibration certificate $\mathrm{Nr} 17688 / 18$, set to take a reading every 30 min (Figure 1).

Seeds of soybean (Glycine $\max$ (L.) Merr.) 'M-Soy 8866' with determinate growth habit and 'HO Cristalino Ipro' of indeterminate growth habit were used. Sowing was carried out at a depth of $5.0 \mathrm{~cm}$ in sufficient quantity to ensure emergence of approximately three seedlings, and shortly after emergence only one healthy plant was maintained.

A completely randomized experimental design was adopted, with seven replicates, and each pot was considered an experimental unit. The experimental treatments consisted of six fractions of the average dose indicated on the label of 2,4$\mathrm{D}$ choline salt herbicide (2-hydroxy- $N, N, N$-trimethylethanaminium (2,4-dichlorophenoxy) acetate), ENLIST COLEX-D; $456 \mathrm{~g}$ ae L ${ }^{-1}$, Dow AgroSciences Industrial Ltda., Barueri, São Paulo, Brazil), as follows: 0 (control), 0.068, 0.684, 6.84, 68.4 and $684 \mathrm{~g}^{2} \mathrm{ha}^{-1}$, that were established based on the dose of $1.5 \mathrm{~L} \mathrm{ha}^{-1}$ recommended on the label, namely: $0 \%$, $0.01 \%, 0.1 \%, 1 \%, 10 \%$, and $100 \%$. The herbicide was sprayed at two distinct soybean phenological stages: second node at the main stem with fully developed leaves (V2) or fifth node at the main stem with fully developed leaves (V5). 
Figure 1. Minimum, maximum and average temperatures in the greenhouse in 2019.

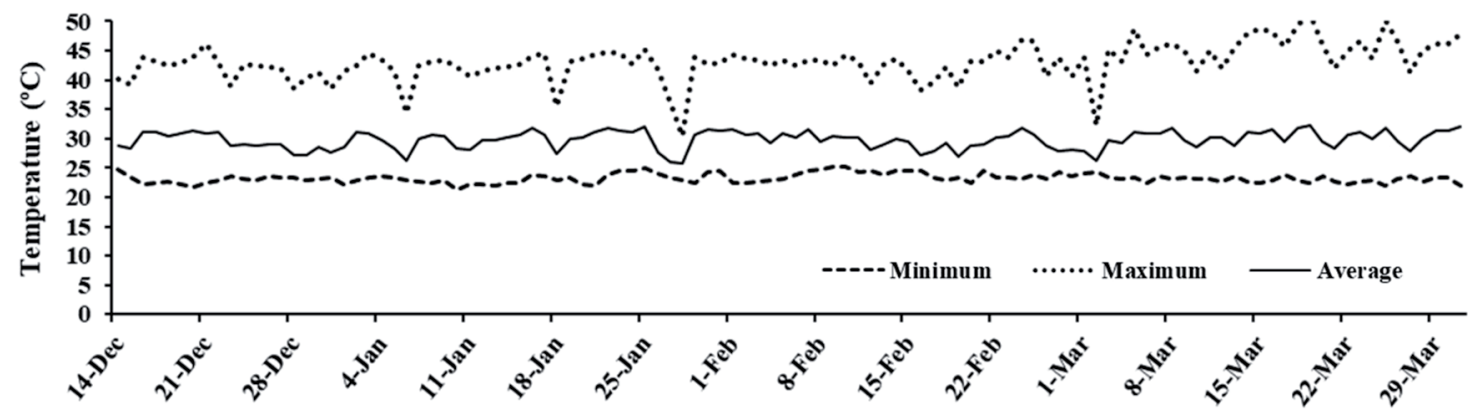

Application of different low doses of a 2,4-D choline salt herbicide was carried out when at least $50 \%$ of the plants were at the phenological stage corresponding to the object of study, with a $\mathrm{CO}_{2}$ pressurized sprayer equipped with spraying boom with four air-induced tips, fan type AIDA 110015, spaced 50 apart, sprayed $50 \mathrm{~cm}$ from the target and calibrated at $1.8 \mathrm{kgf} \mathrm{cm}^{-2}$ to achieve a liquid consumption equivalent to $150 \mathrm{~L} \mathrm{ha}^{-1}$.

Characterization of the soybean plants that received low doses of 2,4-D choline salt applications was conducted at $30 \mathrm{~d}$ after application (DAA) to determine plants height, neck diameter and number of leaves. The plants were then harvested and cut in two parts, between the shoots and roots areas, placed in paper bags and kept in air-circulation oven at $65{ }^{\circ} \mathrm{C}$ during $3 \mathrm{~d}$. The samples were then weighted in a scale with precision of $0.01 \mathrm{~g}$ for determination of the root DM and total DM (roots + shoots).

The values obtained for the cited variables were analyzed by the $\mathrm{F}$ test and the effects of treatments were compared by the Scott-Knott test at 5\% probability level using the statistical program Rbio (Bhering, 2017). When significant, the regression model of Brain and Cousens (1989), adapted by Ritz et al. (2015), was used for analysis of the hormesis effect, with the purpose of describing the dose-response curves with stimulation at low doses:

$$
\mathrm{y}=\mathrm{c}+\frac{\mathrm{d}-\mathrm{c}+\mathrm{fx}}{1+\exp (\mathrm{b}(\log (\mathrm{x})-\log (\mathrm{e})))}
$$

where $\mathrm{y}$ is treatment production; $\mathrm{x}$ is herbicide dose; $\mathrm{e}$ is $\mathrm{ED}_{50}$, which is defined as the dose that provides $50 \%$ of total achievable effect; $d$ is upper limit; $c$ is lower limit; $b$ indicates relative slope around $\mathrm{e} ; \mathrm{f}$ is linear term. The models were assembled by the R package (R Foundation for Statistical Computing, Vienna, Austria. https://www.R-project.org/), and the graphs were plotted by Origin 8.5.1 SR1 software (OriginLab Corporation, Northampton, Massachusetts, USA).

The variables which did not exhibit hormesis were adjusted to the nonlinear polynomial regression model by Origin 8.5.1 SR1. To select the regression model, we considered the highest value of the coefficient of determination $\left(\mathrm{R}^{2}\right)$ at $\mathrm{p} \leq 0.05$, according to the $\mathrm{F}$ test, respecting the biological response.

\section{RESULTS}

Low doses of 2,4-D choline salt herbicide applied at the stage V2 of determinate growth soybean can enhance the plant height and induce a greater production of shoots DM (SDM), root DM (RDM) and total DM (TDM), considering that the hormesis model was significant for these variables, with determination coefficients of 0.97, 0.92, 0.96 and 0.92 , respectively (Table 1, Figure 2).

However, no significance of this model was observed, which considers stimuli at low doses for the number of leaves variable. It should also be emphasized that no model was adjusted for the neck diameter variable, since nonsignificant difference was found between the low doses tested without application of 2,4-D choline salt (Table 1).

The greatest stimuli for height (Figure 2A), SDM (Figure 2B), RDM (Figure 2C) and TDM (Figure 2D) of soybean plants with determinate growth habit onto which low doses of 2,4-D choline salt herbicide was applied at the stage V2, were estimated for the respective doses of $0.20,0.60,0.41$ and $0.44 \mathrm{~g}^{2} \mathrm{e} \mathrm{ha}^{-1}$ of herbicide, exhibiting an increase of 3.63\%, $40.92 \%, 36.50 \%$ and $33.57 \%$, respectively, in relation to the control (Table 1, Figure 2). It should be noted that low doses above the values cited reduced gradually the variables assessed. 
Table 1. Values of $\mathrm{F}$, coefficients of determination and coefficients of regression equations for analysis of biometric variables of soybean plants with determinate growth habit that received applications of 2,4-D choline salt herbicide at the V2 stage. Maximum estimated growth values and herbicide doses for these values.

\begin{tabular}{|c|c|c|c|c|c|c|c|c|c|}
\hline \multirow[b]{2}{*}{ Variable } & \multirow[b]{2}{*}{$\mathrm{F}$} & \multirow[b]{2}{*}{$\mathrm{R}^{2}$} & \multicolumn{5}{|c|}{ Regression parameters with hormesis } & \multicolumn{2}{|c|}{ Maximum values } \\
\hline & & & B & $\mathrm{C}$ & d & $\mathrm{e}$ & $\mathrm{F}$ & $\begin{array}{l}\text { Control } \\
\text { percentage }\end{array}$ & Dose \\
\hline Height, cm & $227.75^{* *}$ & 0.97 & 0.90 & 139.60 & 79.83 & 0.42 & -131.25 & 3.63 & 0.20 \\
\hline SDM, g & $62.23 * *$ & 0.92 & 0.96 & 21.42 & 3.47 & 0.27 & -56.90 & 40.92 & 0.60 \\
\hline RDM, g & $146.86 * *$ & 0.96 & 1.22 & -0.36 & 2.00 & 0.39 & 9.81 & 36.50 & 0.41 \\
\hline \multirow[t]{2}{*}{ TDM, g } & $65.05^{* *}$ & 0.92 & 0.96 & 33.12 & 5.51 & 0.24 & -100.54 & 33.57 & 0.44 \\
\hline & \multicolumn{9}{|c|}{ Regression parameters without hormesis } \\
\hline Variable & $\mathrm{F}$ & $\mathrm{R}^{2}$ & & A & & B & & $\mathrm{c}$ & \\
\hline Nr of leaves & $63.97 * *$ & 0.96 & & 11.04 & & -0.0 & & 0.000 & \\
\hline Neck diameter, mm & $2.24^{\mathrm{NS}}$ & - & & - & & - & & - & \\
\hline
\end{tabular}

**Significant at $1 \%$ probability; NS: nonsignificant.

SDM: Shoots dry matter; RDM: root dry matter; TDM: total dry matter.

Figure 2. Curves representing plant height (A), shoots dry matter (B), root dry matter (C), total dry matter (D) of determinate growth habit soybean applied with low doses of 2,4-D choline salt at stage V2.
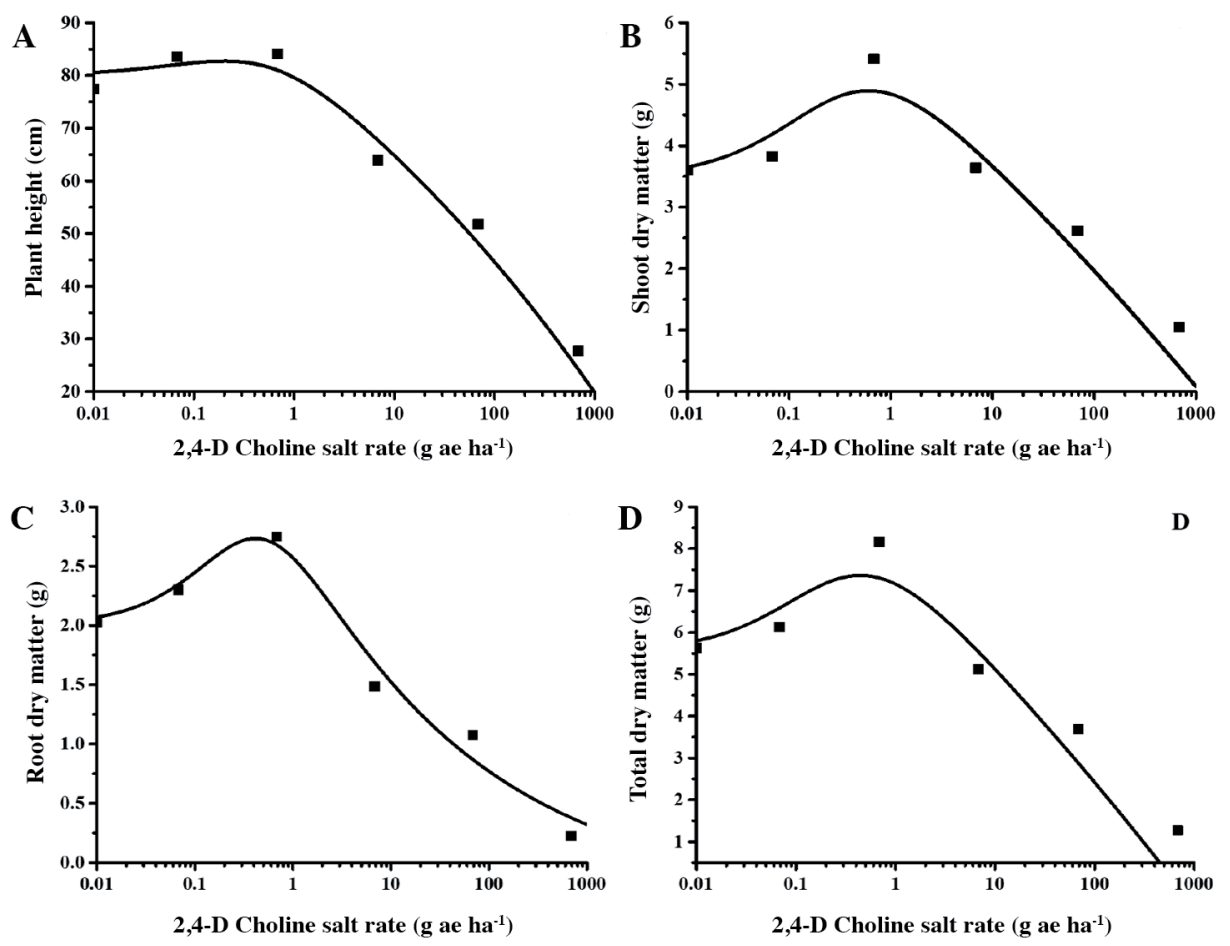

For the indeterminate growth habit cultivars, it was possible to observe that low doses of 2,4-D choline salt applied at stage V2 of the soybean plant may induce a greater production of leaves, SDM, RDM and TDM, with a significant adjustment of the hormesis model for these variables and coefficients of determination higher than 0.91 (Table 2, Figure 3). Hormesis effect was not observed for the height and neck diameter variables, and for this reason data were adjusted to the nonlinear polynomial regression model, indicating $\mathrm{R}^{2}$ values of 0.98 and 0.99 , respectively (Table 2).

It can be seen that the maximum values for the number of leaves (Figure 3A), SDM (Figure 3B), RDM (Figure 3C) and TDM (Figure 3D) of soybean plants with indeterminate growth habit that received applications of low doses of 2,4-D choline salt at stage V2 were estimated for the respective herbicide doses of 36.01, 26.22,2.60 and $19.42 \mathrm{~g}^{2}$ ha ${ }^{-1}$, indicating an increase of $45.90 \%, 43.22 \%, 54.41 \%$ and $30.98 \%$, respectively, compared to the control (Table 2, Figure 3). 
Table 2. Values of F, coefficients of determination and coefficients of regression equations for analyses of biometric variables of soybean plants with indeterminate growth habit which received applications of low doses of 2,4-D choline salt at stage V2. Maximum estimated growth values and herbicide doses for these values.

\begin{tabular}{|c|c|c|c|c|c|c|c|c|c|}
\hline \multirow[b]{2}{*}{ Variable } & \multirow[b]{2}{*}{$\mathrm{F}$} & \multirow[b]{2}{*}{$\mathrm{R}^{2}$} & \multicolumn{5}{|c|}{ Regression parameters with hormesis } & \multicolumn{2}{|c|}{ Maximum values } \\
\hline & & & B & c & D & $\mathrm{e}$ & $\mathrm{F}$ & $\begin{array}{c}\text { Control } \\
\text { percentage }\end{array}$ & Dose \\
\hline $\mathrm{Nr}$ of leaves & $51.60 * *$ & 0.91 & 5.06 & 0.03 & 16.97 & 59.64 & 0.48 & 45.90 & 36.01 \\
\hline SDM, g & $449.55 * *$ & 0.98 & 3.19 & 0.0001 & 6.64 & 48.75 & 0.16 & 43.22 & 26.22 \\
\hline RDM, g & $126.48 * *$ & 0.96 & 1.63 & -0.05 & 3.51 & 3.68 & 1.93 & 54.41 & 2.60 \\
\hline \multirow[t]{2}{*}{ TDM, g } & $169.80 * *$ & 0.97 & 2.65 & -0.02 & 10.49 & 40.34 & 0.27 & 30.98 & 19.42 \\
\hline & \multicolumn{9}{|c|}{ Regression parameters without hormesis } \\
\hline Variable & $\mathrm{F}$ & $\mathrm{R}^{2}$ & \multicolumn{3}{|c|}{$\mathrm{a}$} & \multicolumn{2}{|c|}{ B } & \multicolumn{2}{|c|}{$\mathrm{c}$} \\
\hline Height, $\mathrm{cm}$ & $233.77 * *$ & 0.98 & \multicolumn{3}{|c|}{47.44} & \multicolumn{2}{|c|}{-0.12} & \multicolumn{2}{|c|}{0.000083} \\
\hline Neck diameter, $\mathrm{mm}$ & $424.34 * *$ & 0.99 & \multicolumn{3}{|c|}{3.93} & \multicolumn{2}{|c|}{-0.0069} & \multicolumn{2}{|c|}{0.0000016} \\
\hline
\end{tabular}

**Significant at $1 \%$ probability.

SDM: Shoots dry matter; RDM: root dry matter; TDM: total dry matter.

Figure 3. Curves representing the number of leaves (A), shoots dry matter (B), root dry matter (C), total dry matter (D) of indeterminate growth habit soybean applied with low doses of 2,4-D choline salt at stage V2.
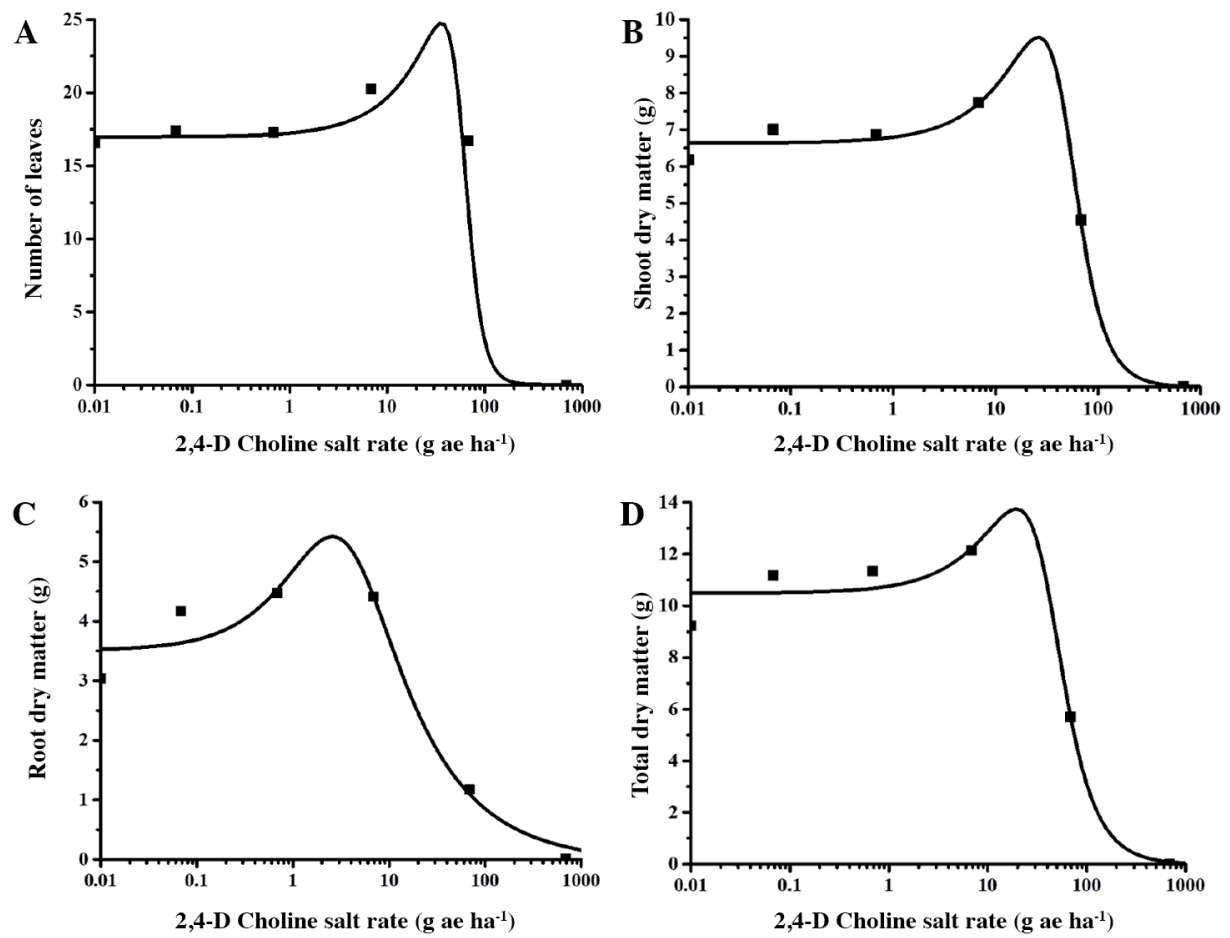

Low doses of 2,4-D choline salt herbicide applied at stage V5 of soybean plants with determinate growth habit may result in greater production of SDM, RDM and TDM, considering that the hormesis model was significant for these variables, exhibiting coefficients of determination of 0.99 (Table 3, Figure 4). However, for the number of leaves, height and neck diameter variables, it was not observed significance of the hormesis model, which considers stimuli at low doses. The data for these variables were adjusted to the nonlinear polynomial regression model, exhibiting $\mathrm{R}^{2}$ values higher than 0.90 (Table 3).

The greatest stimuli for SDM (Figure 4A), RDM (Figure 4B) and TDM (Figure 4C) of soybean plants with indeterminate growth habit onto which low doses of 2,4-D choline salt were applied at stage V5 were estimated for the respective herbicide doses of 1.20, 0.97 and $0.99 \mathrm{~g}^{2}$ ae ha ${ }^{-1}$, exhibiting an increase of $18.50 \%, 16.44 \%$ and $11.19 \%$, respectively, compared to the control (Table 3, Figure 4). It is worth noting that low doses above the values cited gradually diminished the assessed variables, a clear evidence of the herbicide effect of the 2,4-D choline salt. 
Table 3. Values of $\mathbf{F}$, coefficients of determination and coefficients of regression equations for analyses of biometric variables of soybean plants with determinate growth habit which received applications of low doses of 2,4-D choline salt at stage V5. Maximum estimated growth values and herbicide doses for these values.

\begin{tabular}{|c|c|c|c|c|c|c|c|c|c|}
\hline \multirow[b]{2}{*}{ Variable } & \multirow[b]{2}{*}{$\mathrm{F}$} & \multirow[b]{2}{*}{$\mathrm{R}^{2}$} & \multicolumn{5}{|c|}{ Regression parameters with hormesis } & \multicolumn{2}{|c|}{ Maximum values } \\
\hline & & & B & $\mathrm{c}$ & d & E & $\mathrm{F}$ & $\begin{array}{c}\text { Control } \\
\text { percentage }\end{array}$ & Dose \\
\hline SDM, g & $1517.03 * *$ & 0.99 & 1.17 & -4.18 & 6.27 & 1.83 & 6.88 & 18.50 & 1.20 \\
\hline RDM, $g$ & $878.43 * *$ & 0.99 & 1.14 & -5.07 & 6.14 & 1.54 & 8.48 & 16.44 & 0.97 \\
\hline \multirow[t]{2}{*}{ TDM, g } & $767.75^{* *}$ & 0.99 & 1.10 & -16.61 & 12.68 & 1.99 & 15.83 & 11.19 & 0.99 \\
\hline & \multicolumn{9}{|c|}{ Regression parameters without hormesis } \\
\hline Variable & $\mathrm{F}$ & $\mathrm{R}^{2}$ & \multicolumn{3}{|c|}{ a } & \multicolumn{2}{|c|}{ B } & \multicolumn{2}{|c|}{$\mathrm{c}$} \\
\hline $\mathrm{Nr}$ of leaves & $25.11 *$ & 0.90 & \multicolumn{3}{|c|}{11.48} & \multicolumn{2}{|c|}{-0.08} & \multicolumn{2}{|c|}{0.000093} \\
\hline Height, $\mathrm{cm}$ & $50.04 * *$ & 0.95 & \multicolumn{3}{|c|}{71.74} & \multicolumn{2}{|c|}{-0.67} & \multicolumn{2}{|c|}{0.00082} \\
\hline Neck diameter, $\mathrm{mm}$ & $423.57 * *$ & 0.99 & \multicolumn{3}{|c|}{5.16} & \multicolumn{2}{|c|}{0.002} & \multicolumn{2}{|c|}{-0.000014} \\
\hline
\end{tabular}

$*, * *$ Significant at $5 \%$ and $1 \%$ probability, respectively.

SDM: Shoots dry matter; RDM: root dry matter; TDM: total dry matter.

Figure 4. Curves representing the shoots dry matter (A), root dry matter (B), total dry matter (C) of the determinate growth habit soybean applied with low doses of 2,4-D choline salt at stage V5.
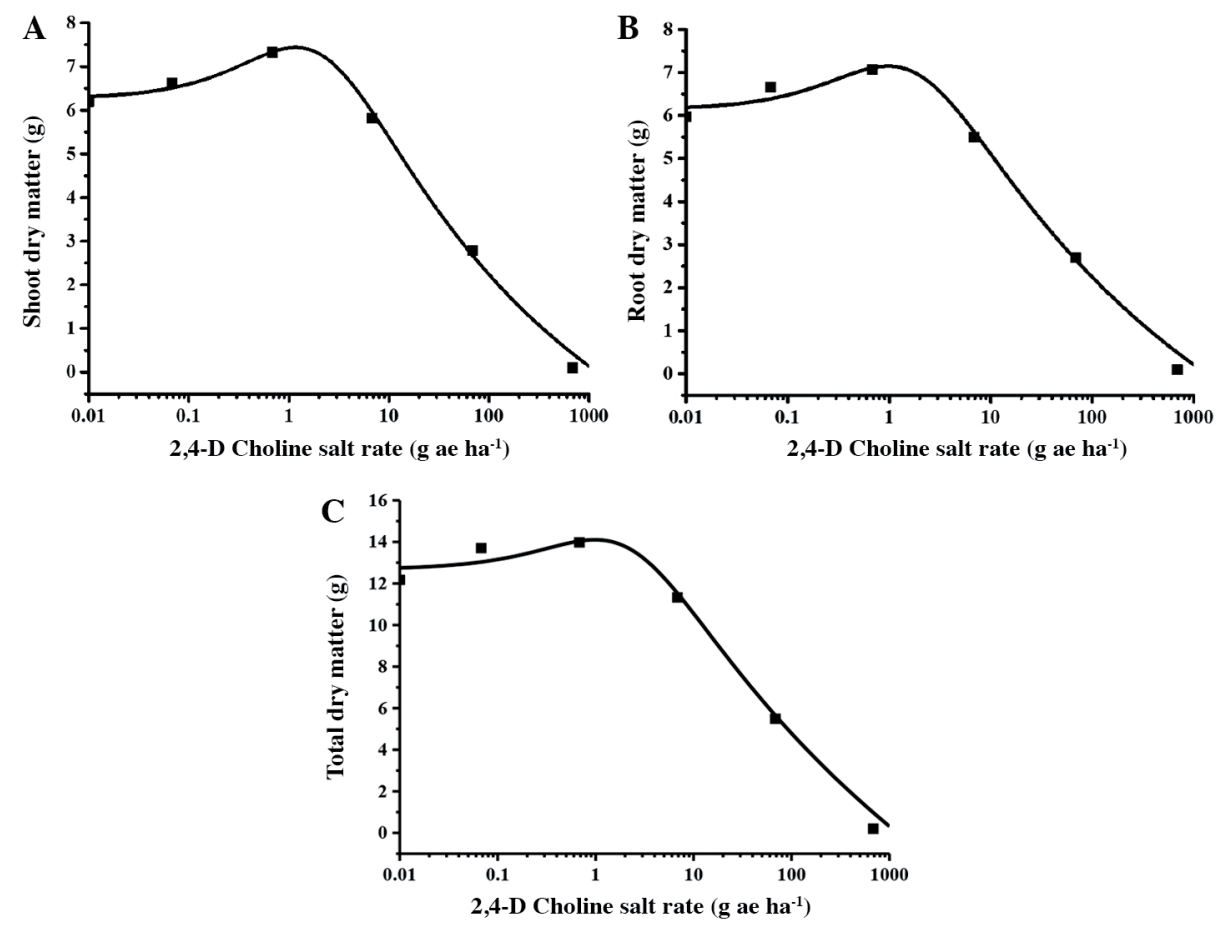

Soybean plants with indeterminate growth habit at stage V5 is negatively affected by application of low doses of 2,4-D choline salt herbicide, considering that the hormesis effect was nonsignificant for the biometric variables assessed. The values relating to height, number of leaves, SDM, RDM, TDM and neck diameter were adjusted to the nonlinear polynomial regression model showing a decreasing behavior as increasing herbicide low doses were applied (Table 4). 
Table 4. Values of $\mathrm{F}$, determination coefficients and coefficients of regression equations for analysis of biometric variables of soybean plants with indeterminate growth habit which received applications of low doses of 2,4-D choline salt herbicide at stage V5.

\begin{tabular}{lccccc}
\hline & & & \multicolumn{3}{c}{ Regression parameters with hormesis } \\
\cline { 4 - 6 } Variable & $\mathrm{F}$ & $\mathrm{R}$ & $\mathrm{A}$ & $\mathrm{B}$ & $\mathrm{c}$ \\
\hline Height, cm & $108.08^{* *}$ & 0.97 & 86.86 & -0.09 & -0.000045 \\
Nr of leaves & $102.35^{* *}$ & 0.97 & 33.49 & 0.01 & -0.000095 \\
SDM, g & $362.61^{* *}$ & 0.99 & 20.67 & -0.09 & 0.000099 \\
RDM, g & $14.34^{*}$ & 0.84 & 15.02 & -0.08 & 0.000089 \\
TDM, g & $57.56^{* *}$ & 0.95 & 35.69 & -0.18 & 0.00018 \\
Neck diameter, $\mathrm{mm}$ & $1689.61^{* *}$ & 0.99 & 8.18 & 0.004 & -0.000024 \\
\hline
\end{tabular}

$*, * *$ Significant at $5 \%$ and $1 \%$ probability, respectively.

SDM: Shoots dry matter; RDM: root dry matter; TDM: total dry matter.

\section{DISCUSSION}

In this research, it was found that low doses of 2,4-D choline salt can enhance some biometric variables of soybean plants, thus supporting the hormesis theory. However, it is clear that the mode of action of this auxinic herbicide may be directly influenced by the dose applied to different cultivars and the plants' phenological stages and may cause different responses. This marks the difference between its action as growth enhancer or as herbicide.

It can be seen that there was adjustment of the hormesis model with applications of low doses of 2,4-D choline salt at stages V2 and V5 of soybean plants with determinate growth habit and only for the stage V2 of cultivar with indeterminate habit cultivar. It should be taken into consideration that hormesis must be considered as an adaptive response characterized by the initial disturbance of the homeostasis state (Calabrese and Mattson, 2017). Homeostasis is defined as the ability to maintain constant stability of the internal state of an organism with efficient functions and performances so as to ensure that a physiologically stable environment is maintained in the face of a disturbance (Brito and Haddad, 2017).

When homeostasis is disturbed, hormesis represents the advantage that an organism has to make use of the resources initially available to repair a damaged tissue, but modestly exceeding what is needed to repair immediate damages caused by the disturbed homeostasis. This process may also readapt the organism against damages from further, more intense exposure within a limited period of time, working as a kind of vaccine (Ademowo et al., 2019).

Accordingly, response may fulfill repair and protection functions against subsequent more severe exposures. However, if a further exposure does not occur, the high production of remedial resources may be used in other functions useful to the organism (Cedergreen et al., 2009).

The increases in plant height and leaves production, as shown in Tables 1 and 2, respectively, may also have occurred because of the interference of 2,4-D herbicide in the cell division and elongation due to the hormonal imbalance that it causes in the cells with increased biosynthesis of ethylene, gibberellins, cytokines, abscisic acid (ABA), leading to a disordered growth of the plant tissue (Oliveira, 2011; Marques et al., 2019).

In general, it was found that the increases that resulted from application of low doses of 2,4-D choline salt between 0.20 and $1.20 \mathrm{~g}$ ae ha $^{-1}$ on determinate soybean plants ranged from $3.63 \%$ to $40.92 \%$ compared to the control, irrespective of the phenological stage. For indeterminate soybean plants at stage V2, the increases ranged from $30.98 \%$ and $54.41 \%$ compared to the control for low doses between 2.60 and $36.01 \mathrm{~g}$ ae ha-1. Duke et al. (2006) describe that in more than 30 cases of plants treatment cultivated with sublethal doses of herbicides, the maximum hormesis response dose can be observed in up to $20 \%$ of the concentration level indicated on the label, with responses that may reach nearly $50 \%$ of increase of the analyzed variable, and the stimuli can be seen in growth characteristics such as gains in weight, height, length and foliar area and/or in internal characteristics such as protein content and sugar levels.

Data of this research evidence that soybean plants with indeterminate growth habit are more resistant to 2,4-D choline salt herbicide than determinate growth plants, both at stage V2. It can be seen, for instance, that the maximum values for SDM, RDM and TDM of soybean plants with indeterminate growth habit (Figure 3) were estimated at the respective herbicide doses of 26.22, 2.60 and $19.42 \mathrm{~g}$ ae ha- $^{-1}$, while for the determinate growth cultivar (Figure 2), the highest stimuli for these variables were estimated at $0.60,0.41$ and $0.44 \mathrm{~g}_{\text {ae }} \mathrm{ha}^{-1}$ herbicide doses, respectively. 
The difference between the mean values of these variables for the different soybean cultivars is also noteworthy. For the TDM variable, for instance, the maximum estimated values at $30 \mathrm{~d}$ after application were approximately $14 \mathrm{~g}$ for indeterminate growth cultivar and $8 \mathrm{~g}$ for determinate growth cultivar.

Soybean growth habit is regulated by its genetic constitution, with the following interaction between genes: Dt1/dt1 and $D t 2 / d t 2$. The $d t 1 d t 1$ gene expresses the determinate growth habit; Dt1Dt1 expresses the indeterminate growth habit and, finally, $D t 1 d t 1$ characterizes the semi-determinate habit. The $D t 2 d t 2$ gene in its dominant form also expresses the semi-determinate phenotype, and the $d t 2 d t 2$ the indeterminate habit (Bernard, 1972).

It is known that indeterminate growth plants generally reach a greater size and uptake larger amounts of resources from the environment, transformed into DM, than those of determinate growth due to the absence of the allele $d t 1$ in its genotype (Sediyama et al., 2009). For this reason, cultivars with indeterminate growth habit have a greater potential to express their morphophysiological characteristic, named plasticity, adapting more easily to the spatial arrangement of the plants (Balbinot Junior et al., 2018).

Because it is an auxin-mimicking herbicide and all auxins are weak acids, the ability of 2,4-D to penetrate the plasma membrane depends on the $\mathrm{pH}$ and is related to it. The apoplastic $\mathrm{pH}$ value in plants is around 5.5. At this $\mathrm{pH}$, the equilibrium of auxin molecules is calculated to be nearly $83 \%$ when dissociated and $17 \%$ when undissociated (or protonassociated). In this case, the negative charge of the carboxylic group dissociated from the molecule will prevent it from crossing the membrane, and only undissociated molecules will be able to enter the plasma membrane by passive diffusion, without requiring the assistance of proteins transporters (Zazimalová et al., 2010).

The cytoplasm of plant cells, in turn, has a pH value close to 7.0, making that the auxin molecules equilibrium shifts almost entirely to dissociated or anionic forms. Because anionic auxins cannot diffuse through the plasma membrane, they are trapped inside the cells (Zazimalová et al., 2010). Therefore, soybean plants with indeterminate growth habit are less sensitive to exposures of lower doses of 2,4-D, which is supposed to be due to the plants' higher vigor when compared to those of determinate habit, thus interfering directly with the passive diffusion of the herbicide, causing less damage to the leaves' cell walls, even after application of high doses (Smith et al., 2017).

Concerning the phenological stage V5, it can be seen that there was a distinct behavior between both soybean cultivars considering that the hormesis model was adjusted for the SDM, RDM and TDM variables only for the soybean with determinate growth habit. Although there was no effect of hormesis for indeterminate plants at stage V5, it should be emphasized that the herbicide effect was observed only for low doses higher than $6.84 \mathrm{~g}$ ae ha ${ }^{-1}$. Egan et al. (2014) used meta-analysis to synthetize seven decades of experimental results on the effects of drift simulation of 2,4-D on soybean and concluded that the species is relatively tolerant to some levels of low doses in all development stages.

Velini et al. (2010) also state that, despite the benefits that can be seen, low doses of herbicides are not recommended as a plant growth stimulant, because the doses that cause the hormesis effect may vary considerably depending on diverse factors, such as formulation, climate conditions and, particularly, the cultivar and the plants' phenological stage.

\section{CONCLUSIONS}

The maximum effect of hormesis on the plant's height, shoots dry matter (SDM), roots dry matter (RDM) and total dry mater (TDM) of soybean plants with determinate growth habit with applications of low doses of 2,4-D choline salt at stage V2 were estimated for the respective herbicide doses of $0.20,0.60,0.41$ and $0.44 \mathrm{~g}^{2}$ ha $^{-1}$. The maximum values for the variables relating to the number of leaves, SDM, RDM and TDM of soybean plants with indeterminate growth habit at stage V2 were estimated for low doses of 36.01, 26.22, 2.60 and $19.42 \mathrm{~g}$ ae ha ${ }^{-1}$ of 2,4-D choline salt herbicide. The highest stimuli for SDM, RDM and TDM of soybean plants with indeterminate growth habit with application of low doses of 2,4-D choline salt at stage V5 were estimated for the respective herbicide doses of 1.20, 0.97 and $0.99 \mathrm{~g}$ ae ha-1. Soybean plants with indeterminate growth habit at stage V5 is negatively affected by application of low doses of 2,4-D choline salt herbicide, considering that the hormesis effect was nonsignificant for the biometric variables assessed. 


\section{ACKNOWLEDGEMENTS}

The authors are thankful to the Coordination of Improvement of Higher Education Personnel (CAPES) and CORTEVA Agriscience for their support to this study.

\section{REFERENCES}

Ademowo, O.S., Dias, H.I., Pararasa, C., and Griffiths, H.R. 2019. Nutritional hormesis in a modern environment. p.75-86. In Rattan, S.I.S., and Kyriazi, M. (eds.) The science of hormesis in health and longevity. Academic Press, Cambridge, Massachusetts, USA.

Americo, G.H.P., Americo-Pinheiro, J.H.P., and Furlani Jr., E. 2017. Hormesis effect of dichlorophenoxy acetic acid sub-doses and mepiquat chloride on cotton plant. Planta Daninha 35:e017166065. doi:10.1590/s0100-83582017350100078.

Balbinot Junior, A.A., Oliveira, M.C.N., Zucareli, C., Ferreira, A.S., Werner, F., and Silva, M.D.A. 2018. Analysis of phenotypic plasticity in indeterminate soybean cultivars under different row spacing. Australian Journal of Crop Science 12:648-654. doi:10.21475/ajcs.18.12.04.pne1003.

Bernard, R.L. 1972. Two genes affecting stem termination in soybean. Crop Science 12:235-239. doi:10.2135/cropsci1972.0011183X001200020028x.

Bhering, L.L. 2017. Rbio: A tool for biometric and statistical analysis using the R platform. Crop Breeding and Applied Biotechnology 17:187-190. doi:10.1590/1984-70332017v17n2s29.

Blanchett, B.H., Grey, T.L., Prostko, E.P., Vencill, W.K., and Webster, T.M. 2017. The effect of 2,4-dichlorophenoxyacetic acid (2,4-D) on peanut when applied during vegetative growth stages. Peanut Science 44:53-59. doi:10.3146/PS16-15.1.

Brain, P., and Cousens, R. 1989. An equation to describe dose responses where there is stimulation of growth at low doses. Weed Research 29:93-96. doi:10.1111/j.1365-3180.1989.tb00845.x.

Brito, I., e Haddad, H. 2017. A formulação do conceito de homeostase por Walter Cannon. Filosofia e História da Biologia 12:99-113.

Brito, I.P., Tropaldi, L., Carbonari, C.A., and Velini, E.D. 2018. Hormetic effects of glyphosate on plants. Pest Management Science 74:1064-1070. doi:10.1002/ps.4523.

Calabrese, E.J., and Mattson, M.P. 2017. How does hormesis impact biology, toxicology, and medicine? NPJ Aging and Mechanisms of Disease 3:1-13. doi:10.1038/s41514-017-0013-z.

Cedergreen, N., Felby, C., Porter, J.R., and Streibig, J.C. 2009. Chemical stress can increase crop yield. Field Crops Research 114:54-57. doi:10.1016/j.fcr.2009.07.003.

Cedergreen, N., Ritz, J.C., and Streibig, B. 2005. Improved empirical models describing hormesis. Environmental Toxicology and Chemistry 24:3166-3172. doi:10.1897/05-014R.1.

Duke, S.O., Cedergreen, N., Velini, E.D., and Belz, R.G. 2006. Hormesis: is it an important factor in herbicide use and allelopathy? Outlooks on Pest Management 17:29-33. doi:10.1564/16feb10.

Egan, J.F., Barlow, K.M., and Mortensen, D.A. 2014. A meta-analysis on the effects of 2,4-D and dicamba drift on soybean and cotton. Weed Sciences 62:193-206. doi:10.1614/WS-D-13-00025.1.

Foloni, L.L. 2016. O herbicida 2,4-D: Uma visão geral. LabCom Total, Ribeirão Preto, Brasil.

Islam, F., Farooq, M.A., Gill, R.A., Wang, J., Yang, C., Ali, B., et al. 2017. 2,4-D attenuates salinity-induced toxicity by mediating anatomical changes, antioxidant capacity and cation transporters in the roots of rice cultivars. Scientific Reports 7:10443-10466. doi:10.1038/s41598-017-09708-x.

Marques, R.F., Marchi, S.R., Pinheiro, G.H.R., Souza, R.M., Assunção, H.F., and Lúcio, F.R. 2019. Hormesis of 2,4-D choline salt in biometric aspects of cotton. Journal of Agricultural Science 11:283-294. doi:10.5539/jas.v11n13p283.

Marques, R.F., Pinheiro, G.H.R., Araújo, P.P.S., Souza, R.M., e Marchi, S.R. 2021. Efeito de subdoses de 2,4-D sal colina nas características da fibra do algodoeiro. Revista Ciência Agronômica 52:e20207249. doi:10.5935/1806-6690.20210022.

Niu, J.,Zhang,Z., Tang, J., Tang, G., Yang,J., Wang, W., et al.2018. Dicationic ionic liquids of herbicide 2,4-dichlorophenoxyacetic acid with reduced negative effects on environment. Journal of Agricultural and Food Chemistry 66:10362-10368. doi:10.1021/acs.jafc.8b02584.

Oliveira Jr., R.S. 2011. Mecanismos de ação de herbicidas. p. 141-148. In Oliveira Jr., R.S., Constantin, J., e Inoue, M.H. (eds.) Biologia e manejo de plantas daninhas. Omnipax, Curitiba, Paraná, Brasil.

Ritz, C., Baty, F., Streibig, J.C., and Gerhard, D. 2015. Dose-Response analysis using R. PLOS ONE 10:e0146021. doi:10.1371/journal.pone.0146021.

Sediyama, T., Teixeira, R.C., e Barros, H.B. 2009. Tecnologias de produção e usos da soja. Mecenas, Londrina, Paraná, Brasil.

Silva, V.M., Silva, T.J.A., Oliveira, M.A.P., Bonfim-Silva, E.M., José, J.V., and Schlichting, A.F. 2018. Initial development of soybean as a bioindicator of the potential of leaching 2,4-D in red latosol. Applied Engineering in Agriculture 34:727-733. doi:10.13031/aea.12761. 
Smith, H.C., Ferrell, J.A., Webster, T.M., and Fernandez, J.V. 2017. Cotton response to simulated auxin herbicide drift using standard and ultra-low carrier volumes. Weed Technology 31:1-9. doi:10.1614/WT-D-16-00101.1.

Tavares, C.J., Pereira, L.S., Araújo, A.C.F., Martins, D.A., e Jakelaitis, A. 2017. Crescimento inicial de plantas de pequi após aplicação de 2,4-D. Pesquisa Florestal Brasileira 37(89):81-87.

Vanneste, S., and Friml, J. 2009. Auxin: a trigger for change in plant development. Cell 136:1005-1016. doi:10.1016/j.cell.2009.03.001.

Velini, E.D., Carbonari, C.A., Trindade, M.L.B., Gomes, G.L.G.C., and Antuniassi, U.R. 2017. Variations in pesticide doses under field conditions: Pesticide dose variation. p. 47-60. In Duke, S.O., Kudsk, P., and Solomon, K. (eds.) Pesticide dose: Effects on the environment and target and non-target organisms ACS Symposium Series. Vol. 1249. ACS Publications, Washington, D.C., USA.

Velini, E.D., Trindade, M.L., Barberis, L.R.M., and Duke, S.O. 2010. Growth regulation and other secondary effects of herbicides. Weed Science 58:351-354. doi:10.1614/WS-D-09-00028.1.

Zazimalová, E., Murphy, A.S., Yang, H., Hoyerová, K., and Hošek, P. 2010. Auxin transporters - why so many? Cold Spring Harbor Perspectives in Biology 2(3):a001552. doi:10.1101/cshperspect.a001552. 